\title{
Protective Effect of 5-HTTLPR (S) and VNTR (10) Allele Combinations of 5-HTT Gene Against Adenotonsillary Hypertrophy
}

\section{5-HTT Geninin 5-HTTLPR (S) ve VNTR (10) Alel Kombinasyonlarının Adenotonsiller Hipertrofiye Karşı Koruyucu Etkisi}

 \\ ${ }^{1}$ Yildırım Beyazıt University, Yenimahalle Education and Research Hospital, Otolaryngology Clinic, Ankara, Turkey \\ ${ }^{2}$ Adana Alparslan Türkeş Science and Technology University, Faculty of Engineering, Department of Bioengineering, Adana, Turkey \\ ${ }^{3}$ Adana City Training and Research Hospital, Health Science University, Adana, Turkey.
}

Cite as: Muz SE, Özdaş S, Özdaş T, Huntürk A, Baştimur S, ÖzI, Canatar İ. Protective Effect of 5-HTTLPR (S) and VNTR (10) Allele Combinations of 5-HTT Gene Against Adenotonsillary Hypertrophy. Kocaeli Med J 2021;10(2):6-15

\section{Abstract}

INTRODUCTION: Serotonin transporter protein which is coded by 5HTT gene is responsible for presynaptic reuptake of serotonin. In this study, we investigated the relationship between polymorphisms in the promoter region (5-HTTLPR) and in the second intron (VNTR) in the 5-HTT gene and adenotonsillar hypertrophy (ATH) in pediatric cases.

METHODS: Genotyped of the 5-HTT gene promotor 5-HTTLPR and intronic VNTR of in 197 children were analyzed using Snap Shot, Multifactor Dimensionality Reduction (MDR) software and carried out to assess the interactions among two polymorphisms and phenotype.

RESULTS: A total of 119 children with ATH (48 girls, 71 boys age range: $3-10$ years; mean age: 5.38 years) and 78 healthy children ( 27 girls, 51 boys, age range: $4-13$ years; mean age: 6.76 years) were included in this study. The frequencies of the genotype in all of inheritance models of the 5-HTTLPR and the VNTR (10) allele showed no significant differences between ATH patient and healthy controls (for all P> 0.05). However, frequency of the 5-HTTLPR (S) allele and VNTR_5-HTTLPR (10/S) haplotype and $(10 / 10+\mathrm{S} / \mathrm{S})$ diplotype were significantly higher in the control group compared to ATH cases $(\mathrm{P}=0.048$, $\mathrm{P}=0.041, \mathrm{P}=0.13$ ).

DISCUSSION AND CONCLUSION: In this study, we observed that S/S genotype, 10/S haplotype and 10/10 + S/S diplotype of 5-HTT gene could have protective effect against ATH.

Keywords: adenotonsillar hypertrophy, serotonin transporter, VNTR, 5-HTTLPR, snap-shot

Öz

GİRIŞ ve AMAÇ: 5HTT geni tarafından kodlanan serotonin taşıyıcı protein, serotoninin presinaptik geri alımından sorumludur. Bu çalışmada pediatrik olgularda 5-HTT genindeki promotör (5-HTTLPR) ve ikinci intron (VNTR) bölgedeki polimorfizmler ile adenotonsiller hipertrofi (ATH) arasındaki ilişkiyi araştırdık.

YÖNTEM ve GEREÇLER: 197 çocuğun 5-HTT gen promotor 5-HTTLPR ve intronic VNTR'si Snap Shot ile genotiplendirilerek, polimorfizmlerin birbiri ve fenotip arasındaki etkileşimler Çok Faktörlü Boyut Azaltma (Multifactor Dimensionality Reduction; MDR) programı ile analiz edildi.

BULGULAR: Çalışmaya ATH tanısı almış 119 hasta (48 kız, 71 erkek yaş aralığı: 3-10 yıl; ortalama yaş: 5.38 yıl) ve 78 sağlıklı çocuk (27 kız, 51 erkek, yaş aralığı: 4-13 yıl; ortalama yaş: 6.76 yıl) dahil edildi. 5-HTTLPR (S) ve VNTR (10) allelinin tüm kalıtım modellerinde genotipik frekanslar açısından, ATH'li ile kontrol grubu arasında anlamlı bir fark gözlenmedi (tümü için $\mathrm{P}>0.05$ ). Bununla birlikte, 5-HTTLPR (S) allel ve VNTR_5-HTTLPR (10 / S) haplotip ve (10/10 + S / S) diplotipinin sıklığ1 ATH olgularına göre kontrol grubunda anlamlı olarak daha yüksekti (sırasıyla, $\mathrm{P}=0.048, \mathrm{P}=0.041, \mathrm{P}=0.13$ ).

TARTIŞMA ve SONUÇ: 5-HTT geninin S / S genotipi, 10 / S haplotipi ve 10/10 + S / S diplotipinin ATH'ye karşı koruyucu etkisi olabilir.

Anahtar Kelimeler: adenotonsiller hipertrofi, serotonin taşıyıcı, VNTR, 5-HTTLPR, snap-shot
Geliş tarihi / Received: 06.01.2020

Kabul tarihi / Accepted: 05.04.2021

Sorumlu Yazar/Corresponding Author: Sibel Özdaş

Adana Alparslan TürkeșScience And Technology University, Faculty of Engineering, Department of Bioengineering, Adana, Turkey sozdas@atu.edu.tr ORCID: 0000-0003-4610-2785

S.E. Muz 0000-0002-4255-4939

T. Özdaș 0000-0003-3651-1892

M.H. Atilla 0000-0001-6400-5888

S. Baștimur 0000-0001-8727-6445

I. Öz 0000-0002-7380-4566

I. Canatar 0000-0001-9448-8112 


\section{INTRODUCTION}

Adenoids and tonsils are located at the entrance of respiratory tract and are important components lymphoid tissues known as Waldeyer's ring. Adenotonsillar hypertrophy (ATH) is the result of chronic inflammation of the adenoid and/or tonsil tissue however, the pathophysiology of this inflammation remains unclear (1). ATH is frequently seen in pediatric population and can cause obstructive sleep apnea (OSA) by airway obstruction that can lead to growth failure, academic learning difficulties, and behavioral problems $(2,3)$.

Increased immunologic activity results with ATH which is one of the most common indications for adenotonsillectomy. The immunological responses, may change the progress and severity of the inflammatory processes may result in structural changes in the airway such as fibrosis, increased thickness of the airway smooth muscle layer, hyperplasia of mucus-secreting cells, and new vessel formation (4).

Serotonin (5-hydroxytryptamine 5HT) is a neurotransmitter which contributes regulation of visceral and physiologic functions in human body and causes bronchoconstriction in most animal. Functional alterations in serotonin receptors and serotonin transporters are thought to be associated with neuropsychiatric and visceral diseases. Serotonin acts through several receptor types located on postsynaptic membranes. Presynaptic reuptake is the mechanism of inactivation of synaptic serotonin in which serotonin transporters (SERT or 5HTT) are responsible. The serotonin transporter proteins are coded by 5 -HTT gene located on chromosome 17q12. Two polymorphisms, VNTR (variablenumber-tandem repeats of $17 \mathrm{bp}$ sequence in the second intron) and 5-HTTLPR (5-HTT gene-linked polymorphic region which is a deletion/insertion polymorphism in the promoter), have been described for 5-HTT gene. VNTR has five alleles (STin 2.7, STin 2.9, STin2.10, STin 2.11 and STin 2.12). 5-HTTLPR has two alleles (S for short and L for long) (5).

Various genetic polymorphisms and their combinations can change the severity of the chronic inflammatory diseases through changing the level of expression of genes $(6,7)$. Recently some studies focused on the relation between VNTR and 5-HTTLPR polymorphisms of 5-HTTgene and obstructive sleep apnea (OSA) (8). Significant association was observed between 5-HTTLPR L allele and severity of OSA in older adults (9). Also, plasma serotonin levels are reported to be elevated in asthma and are significantly related to asthma severity $(10,11)$. OSA is characterized by repetitive pauses in breathing during sleep despite the effort to breathe, caused by obstruction of the airway. Serotonin delivery is reduced to upper airway dilatator

neurons in sleep, leading to sleep related reductions in

dilatator muscle activity and upper airway obstruction (11). Muscle tonus of nasopharynx, palate, oropharynx and tongue also contribute to patency of upper airway and pooling of secretions due to reduced dilatator muscle activity may lead an increase in frequency of upper air way infections. We suggested that polymorphisms of 5-HTT gene could play a role in ATH formationeither as contributing agents or biomarkers.

The aim of this study is to investigate the relationship between VNTR and 5-HTTLPR polymorphisms of the serotonin transporter gene and adenoid hypertrophy in pediatric patients.

\section{MATERIALS AND METHODS}

\section{Subject and Recruitment}

This case-control study involved 197 children (119 patients with ATH and 78 healthy children) under 18 years of age who were admitted to Department of Otolaryngology between January 2014 September 2015. The study was approved by the local ethics committee (ID No: 99950669/137), and written informed consent was obtained from all of the participants and/or their parents/ guardians.

The patient group was comprised of 119 pediatric patients with the diagnosis of ATH who underwent either a total tonsillectomy, a tonsillectomy with adenoidectomy, or an adenoidectomy. The diagnosis of ATH was based on history, otorhinolaryngologic examination and flexible fiberoptic nasopharyngoscopy and/or direct adenoid X-ray.

For determining whether to perform each tonsillectomy was made according to the diagnostic criteria for tonsillectomy defined by the American Otolaryngology and Head Neck Surgery Academy (12). Adenoidectomy were performed in the symptomatic patients with upper respiratory tract infections 4-5 times per year combined with nasal congestion, snoring, mouth breathing, sleeping with their mouths open, irritable sleeping, and sleep apnea, the degree of obstruction for diagnose is determined to have $75 \%$ or above choanal obstruction in the nasopharynx with adenoid tissue by endoscopic examination. We excluded all patients with proven immunodeficiency, diabetes mellitus, renal failure, sinonasal diseases, chronic periodontal disease, inflammatory bowel disease, congenital or genetic disorder, known malignancy or other pathological diseases.

Control group was comprised of 78 healthy volunteers and selected among children who were known as being healthy for more than one yearby our outpatient clinic follow-up. Children who have high mallampati grade, unilateral choanal atresia, chronic disease such as asthma and obesity and history of adenotonsillectomy, craniofacial abnormalities, neuromuscular disease and chronic tonsillitis or symptoms/signs of acute, recurrent respiratory tract infection were excluded from the control group.

The presence of witnessed sleep apnea, open-mouth sleeping, snoring and allergy in children were primarily based on clinical history with the help of parents (13). The presence of asthma was based on the children' medical history or examinations in the department of pulmonology (14).

\section{DNA Isolation}

DNA was extracted from peripheral blood samples $(200 \mu \mathrm{L})$ collected from each patient and healthy subject. QIAamp DNA Blood Mini Kit (Qiagen Inc.) was used for DNA extraction and 
extracted DNA was kept under $-20^{\circ} \mathrm{C}$.

\section{PCR Analysis}

A repetitive region of 44-base pair (bp) located in the promoter region (5-HTTLPR) of the 5-HTT gene was amplified by PCR. The PCR reaction mixture constituted of $0.5 \mu \mathrm{L}$ dNTP (10 $\mu \mathrm{M}$ concentration), $1 \mu \mathrm{L}$ of forward primer 5'-CACCTAACCCCTAATGTCCCTACTGC-3' (5 $5 \mathrm{M})$ and $1 \mu \mathrm{L}$ of revers primer 5'-AGAGGGACTGAGCTGGACAACCAC-3' $(5 \mu \mathrm{M}), 0.2 \mu \mathrm{L}$ of SuperHotTaq DNA polymerase (Bioron Inc.), $5 \mu \mathrm{L}$ of Taq buffer and $20-50 \mathrm{ng} / \mu \mathrm{L}$ of template DNA. PCR thermal conditions comprised of an initial denaturation at $95^{\circ} \mathrm{C}$ for 10 minutes, followed by denaturation for 45 seconds at $95^{\circ} \mathrm{C}$ (35 cycles/minute), annealing for 45 seconds at $60^{\circ} \mathrm{C}$ (35 cycle/ minute), extension for 45 seconds at $72^{\circ} \mathrm{C}$ (35 cycle/minute) and final extension for 10 minutes at $72^{\circ} \mathrm{C}$. The amplified DNA fragments were analyzed by $2 \%$ agarose gel electrophoresis. Ethidium bromide was used to stain DNA fragments in the gel for visualization. Alleles were classified as $\mathrm{S}$ for short (463-bp) and $\mathrm{L}$ for long (507-bp).

Repetitive region of 17-bp located in the second intron (VNTR) of the 5-HTTgene was also amplified by PCR. The PCR reaction mixture constitutedof $0.5 \mu \mathrm{LdNTP}(10 \mu$ Mconcentration $), 1 \mu$ Lofforwardprimer 5'-CTCTCAGTGATTGGCTATGCTGTGG-3' (5 $\mu \mathrm{M})$ and $1 \mu \mathrm{L}$ of reverse primer 5'-CATCATGTTCCTAGTCTTACGCCAGTG-3'

$(5 \mu \mathrm{M}), 0.2 \mu \mathrm{L}$ of SuperHotTaq DNA polymerase (Bioron Inc.), 5 $\mu \mathrm{L}$ of Taq buffer and $20-50 \mathrm{ng} / \mu \mathrm{L}$ of template DNA. Same thermal cycle was used and the amplified DNA fragments were analyzed by $2 \%$ agorose gel electrophoresis. Alleles were classified as 12 for 380-bp and 10 for 346-bp.
In the literature, several types of serotonin transporter protein gene polymorphisms have been described. Due to economic reasons, we could only work on 5-HTTLPR and VNTR.

\section{Statistical analysis}

All the statistical analyses were implemented with the SPSS 16.0 package program (Statistical Package for Social Sciences; version 11.0, SSPS Inc, Chicago, IL, USA). The $\chi 2$ test or Fisher's exact test were used to assess the difference between the genotypes and clinical phenotypes. Also, genotypes and haplotypes analysis were detected using a regressed logistic model, expressed as the odds ratio (OR) and 95\% confidence interval $(95 \% \quad \mathrm{CI}) \quad$ (http://bioinfo.iconcologia.net/index. php?module=Snpstats) Multifactor Dimensionality Reduction (MDR) software package (version 1.0.0, available at www. epistasis.org) was used to evaluate possible relationship between genotype-genotype and genotype-phenotype (15). All statistical analyses were considered significant at $\mathrm{P}<0.05$.

\section{RESULTS}

\section{Characteristics of Study Participants}

A total of 119 children with ATH (48 girls, 71 boys age range: 3 -10 years; mean age: 5.38 years) and 78 healthy children (27 girls, 51 boys, age range: $4-13$ years; mean age: 6.76 years) were included in this study. There was no significant age and gender difference between the patient and control groups $(\mathrm{P}>$ 0.05) (Table 1). The frequency of asthma, allergy witnessed sleep apnea, open-mouth sleeping and snoring in the children with $\mathrm{ATH}$ were significantly higher $(\mathrm{P}=0.017, \mathrm{P}=0.037, \mathrm{P}=$

Table 1. Characteristics of the study population

\begin{tabular}{|c|c|c|c|c|c|}
\hline \multirow{2}{*}{ Clinical Features } & \multirow{2}{*}{$\begin{array}{c}\text { Patients with ATH } \\
\text { (n:119) }\end{array}$} & \multirow{2}{*}{$\begin{array}{c}\text { Healthy children } \\
(\mathrm{n}: 78)\end{array}$} & \multirow[t]{2}{*}{$\mathbf{P} \#$} & \multicolumn{2}{|c|}{$\mathbf{P} \neq$} \\
\hline & & & & VNTR & 5-HTTLPR \\
\hline Age (years) $($ mean $\pm \mathrm{SD})$ & $5.38[2.013 ; 3-10]$ & $6.76[3.998 ; 4-13]$ & 0.550 & 0.566 & 0.387 \\
\hline \multicolumn{6}{|l|}{ Gender, n (\%) } \\
\hline Male & $71(60)$ & $51(65)$ & \multirow{2}{*}{0.592} & \multirow{2}{*}{0.699} & \multirow{2}{*}{0.639} \\
\hline Female & $48(40)$ & $27(35)$ & & & \\
\hline Asthma (+), n (\%) & $32(27)$ & $8(10)$ & 0.017 & 0.550 & $0.512 *$ \\
\hline Allergy (+), n (\%) & $32(27)$ & $9(12)$ & $\mathbf{0 . 0 3 7}$ & 0.168 & $0.504 *$ \\
\hline Witnessed sleep apnea $(+), \mathrm{n}(\%)$ & $99(83)$ & $12(15)$ & $<0.001$ & $<0.001 *$ & 0.102 \\
\hline Open-mouth sleeping (+), n (\%) & $42(53)$ & $6(12)$ & $<0.001$ & 0.178 & 0.614 \\
\hline Snoring (+), n (\%) & $57(72)$ & $6(12)$ & $<0.001$ & $<.001 *$ & 0.108 \\
\hline Tonsillectomy and Adenoidectomy & $65(55)$ & $0(0)$ & - & - & - \\
\hline Tonsillectomy & $43(36)$ & $0(0)$ & - & - & - \\
\hline Adenoidectomy & $11(9)$ & $0(0)$ & - & - & - \\
\hline
\end{tabular}

$\dagger$ Derived from two-sided $X^{2}$ test for comparison of discrete variables and paired Student's $t$-test for continuous variables.

*Fisher's Exact Test between cases and controls P\#

value between cases and controls

$P \neq$ value between variables and individual SNPS

Values are presented as median $\pm S D$ or numbers (\%) unless otherwise specified; $S D=$ Standard deviation; SDB=Sleep disordered-breathing; OMS= Open mouth sleeping 
0.001 and $\mathrm{P}=0.001$, respectively). Among the children with ATH, $65(55 \%)$ patients underwent both tonsillectomy and adenoidectomy, 43 (36\%) underwent tonsillectomy, and 11 (9\%) underwent adenoidectomy (Table 1).

\section{Genotyping}

The individual polymorphisms analyses revealed that there was no difference for each individual-polymorphisms frequency of the VNTR and 5-HTTLPR $(\mathrm{P}=0.814, \mathrm{P}=0.492)$. There was no significant difference for the frequency of each individualpolymorphisms of 5-HTTLPR and VNTR in patient group for asthma, allergy and open-mouth sleeping variables. However, in the patient group frequency of VNTR was high for the witnessed sleep apnea and snoring variables $(\mathrm{P}=0.001$ and $\mathrm{P}=0.001)$ (Table 1).

A study conducted on 1,132 subjects in Turkey obtained a frequency of adenoid hypertrophy of $27 \%$ for 5-7-year-old children, and $19.5 \%$ for $8-10$-year-old children (16). Taking the prevalence of adenoid hypertrophy into consideration, the smallest sample size required to achieve $72 \%$ confidence was determined to be 90 cases (17). Therefore, we enrolled 119 patients with ATH and 78 healthy children to our study.

Minor allele frequencies (MAF) of the VNTR and 5HTTLPR polymorphisms are given in table 2. The VNTR and 5-HTTLPR genotype distributions and allele frequencies of the patients and the controls are shown in table 3. The VNTR and 5-HTTLPR genotype frequencies in all of inheritance models with covariates did not differ significantly between the patient and control groups (for all $\mathrm{P}>0.05$ ). Similarly, the frequencies of the VNTR 10 (0.30 vs. 0.30$)$ was not significantly different between patient and control groups but 5-HTTLPR S (0.42 vs. $0.50)$ allele was significantly different in both groups $(\mathrm{P}=0.92$ and $\mathrm{P}=0.04)$.

Haplotype analysis demonstrated that VNTR_5-HTTLPR $(10 / \mathrm{L})$ haplotype was observed higher in the patient with ATH $(\mathrm{OR}=0.74,95 \% \mathrm{CI}, 0.28-1.98, \mathrm{P}=0.049)$. Whereas in the control group VNTR_5-HTTLPR (10/S) haplotype occurred more frequently $(\mathrm{OR}=2.47,95 \% \mathrm{CI} 0.51-11.85, \mathrm{P}=0.040)($ Table 4).
The frequencies of the VNTR and 5-HTTLPR genotype, allele and haplotype were not statistically significantly different in patients that underwent tonsillectomy, adenoidectomy, and tonsillectomy+adenoidectomy groups $(\mathrm{P}>0.05)$.

\section{Interactions of the Genotype-Genotype and Genotype-Phenotype}

Data of logistic regression analysis performed by MDR was given in figures 1 and 2. Each best model across all possible combinations was assessed by the testing balanced accuracy (TBA), cross-validation consistency (CVC), and significance level to explore the potential interaction of two individual VNTR and 5-HTTLPR in the 5-HTT gene.

According to single locus model 5-HTTLPR has a predictive value for ATH. Children with wild type (L/L) homozygosity or heterozygosity genotype (L/S) for 5-HTTLPR had 2 and 1.5-fold increased risk of having ATH when children who had mutant type genotype (S/S) homozygosity had 1.2-fold protective effect against ATH (Figure 1) (TBA: 0.436, CVC 6/10, OR 1.9304, Cl 0.5572-6.6881, $\mathrm{P}=0.04)$.

According to double locus model, togetherness of VNTR with 5-HTTLPR had predictive factor for AH. Children who had homozygosity mutant type genotype (10/10+S/S) of both VNTR and 5-HTTLPR polymorphisms had 1.2-fold protective effect against ATH when compared with children who had wild type (12 and L) alleles genotype for these polymorphisms (Figure 2) (TBA: 0.522, CVC 10/10, OR 1.2013, CI 0.129-11.1888, P= $0.13)$.

According to three factor model VNTR and 5-HTTLPR genotypes had predictive value for allergic-ATH. Wild type homozygosity $(12 / 12+\mathrm{L} / \mathrm{L})$ and mutant type homozygosity $(10 / 10+\mathrm{S} / \mathrm{S})$ for both polymorphisms was not observed in the study group. Children having genotype combination of $10 / 10+\mathrm{L} / \mathrm{S}, 12 / 12+\mathrm{L} / \mathrm{S}, 12 / 12+\mathrm{S} / \mathrm{S}$ and $12 / 10+\mathrm{L} / \mathrm{S}$ of $5 H T T$ gene had increased risk of having allergic-ATH when compared with allergic-control group. Polymorphism of VNTR and 5-HTTLPR had relation with presence of allergy (Figure 3A, 3B) (TBA 0.563, CVC 10/10, OR 4.6465, CI 2.1195-10.1861, $\mathrm{P}=0.0001$ ).

Table 2. Results from genotyping for 5-HTT gene

\section{MAF}

Genotyped



5-HTT = 5-Hydroxytryptamine transporter; VNTR= Variable number of tandem repeats; 5-HTTLPR= 5-HTT gene-linked polymorphic region; $S=14-$ repeat short (486b); L= 16-repeat long (529bp);

SNP ID= Single-nucleotide polymorphism accession number or NCBI dbSNP (http:www.ncbi.nlm.nih.govsnp);

$M A F=$ Minor allele frequencies;

*MAF from the HapMap databases (http:www.hapmap.org) or NCBI dbSNP (http:www.ncbi.nlm.nih.govsnp);

**MAF from healthy control groups in independent studies on Turkish population 
Table 3. Frequencies of 5-HTT gene SNPs genotype and allele

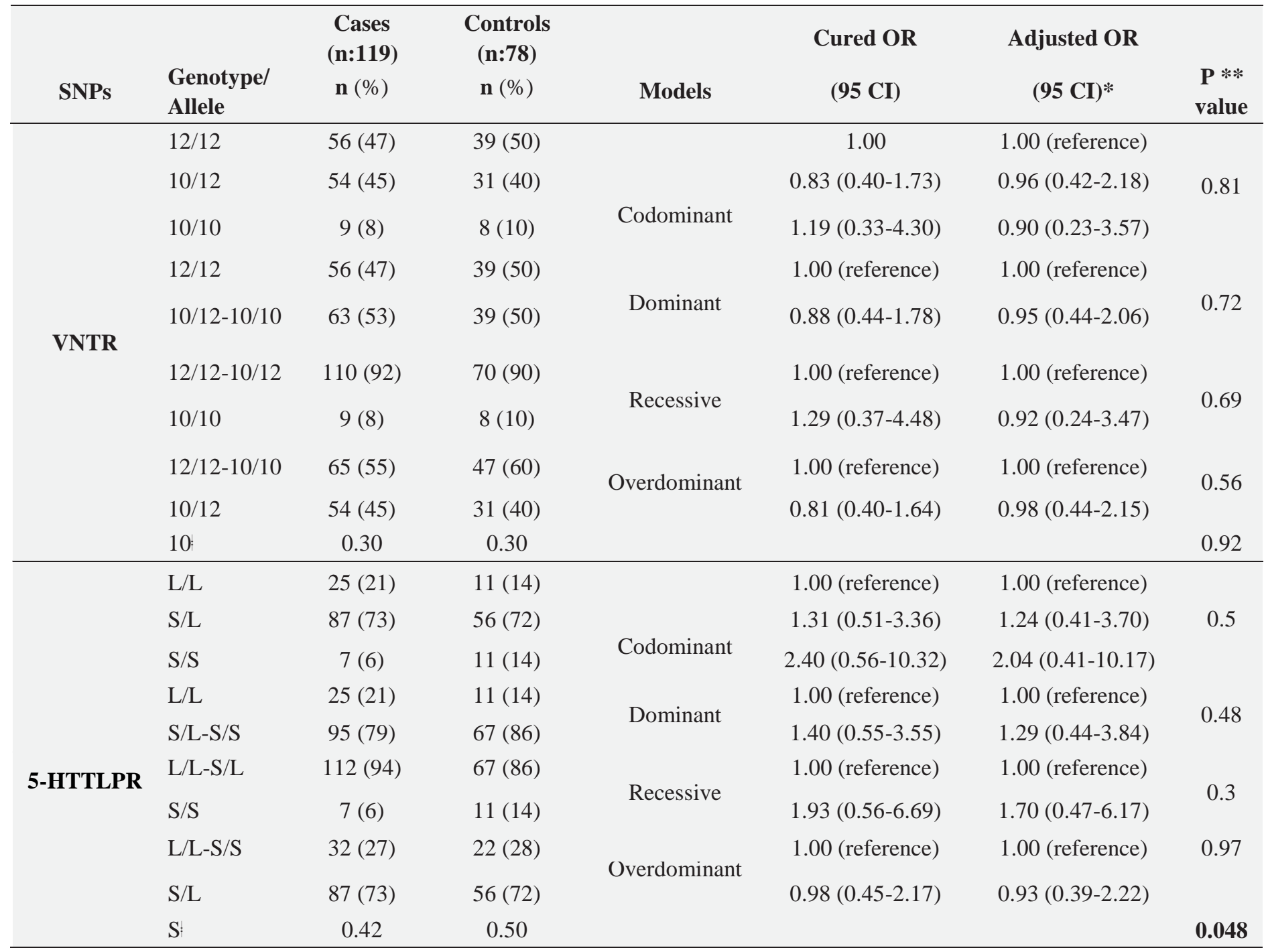

5-HTT = 5-Hydroxytryptamine transporter; VNTR= Variable number of tandem repeats; 5-HTTLPR= 5-HTT gene-linked polymorphic region; S= 14-repeat short (486bp); L= 16-repeat long (529bp); SNP= Single nucleotide polymorphism; OR= Odds ratio; CI=Confidence interval *Adjusted for age and sex,

$* * \chi^{2}$ test

Assumed risk alleles;

$n(\%)=$ Frequency;

Table 4. Associations between risk of $\mathrm{AH}$ and frequencies of haplotypes on the basis of the observed 5-HTT genotypes among cases and controls.

\begin{tabular}{|c|c|c|c|c|c|c|c|}
\hline \multirow{2}{*}{ No } & \multicolumn{2}{|c|}{ Haplotypes } & \multicolumn{3}{|c|}{ Haplotype frequencies } & \multirow{2}{*}{ Cure OR $(95 \% \text { CI })^{*}$} & \multirow[b]{2}{*}{$* * \mathbf{P}$ value } \\
\hline & VNTR & 5-HTTLPR & Cumulative & Cases & Controls & & \\
\hline 1 & 12 & $S$ & 0.3535 & 0.3709 & 0.3453 & 1.00 (reference) & --- \\
\hline 2 & 12 & $\mathrm{~L}$ & 0.6985 & 0.3254 & 0.3566 & $1.49(0.38-5.88)$ & 0.57 \\
\hline 3 & 10 & $\mathrm{~L}$ & 0.9032 & 0.2443 & 0.1626 & $0.74(0.28-1.98)$ & 0.049 \\
\hline 4 & 10 & $S$ & 1 & 0.0595 & 0.1355 & $2.47(0.51-11.85)$ & 0.040 \\
\hline
\end{tabular}

5-HTT = 5-Hydroxytryptamine transporter; VNTR= Variable number of tandem repeats; 5-HTTLPR= 5-HTT gene-linked polymorphic region; S= 14-repeat short (486 bp); $L=16$-repeat long (529bp); $S N P=$ Single nucleotide polymorphism; OR= Odds ratio; CI=Confidence interval Values are presented as $(\%)$

* In logistic regression model.

**Global haplotype association P-value $=0.048$ 




Controls with no AH

Cases with AH

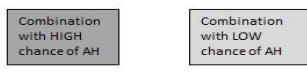

Figure 1: Distribution of the 5-HTTLPR genotypes in cases and controls in application of MDR.

The single-locus model demonstrating effect of the 5-HTTLPR which is able to correctly predict AH with $43.68 \%$ accuracy. The 5-HTTLPR, $L / L$ and $L / S$ genotypes had a 2-fold and 1.52-fold increased risk of $A H$, respectively. For each genotype, the number of cases is displayed in the histogram on the left in each cell while the number of controls is displayed by the histogram on the right. Darker shade indicates the high-risk group (TBA: 0.436, CVC 6/10, OR 1.9304, CI 0.5572-6.6881, $P=0.04)$.
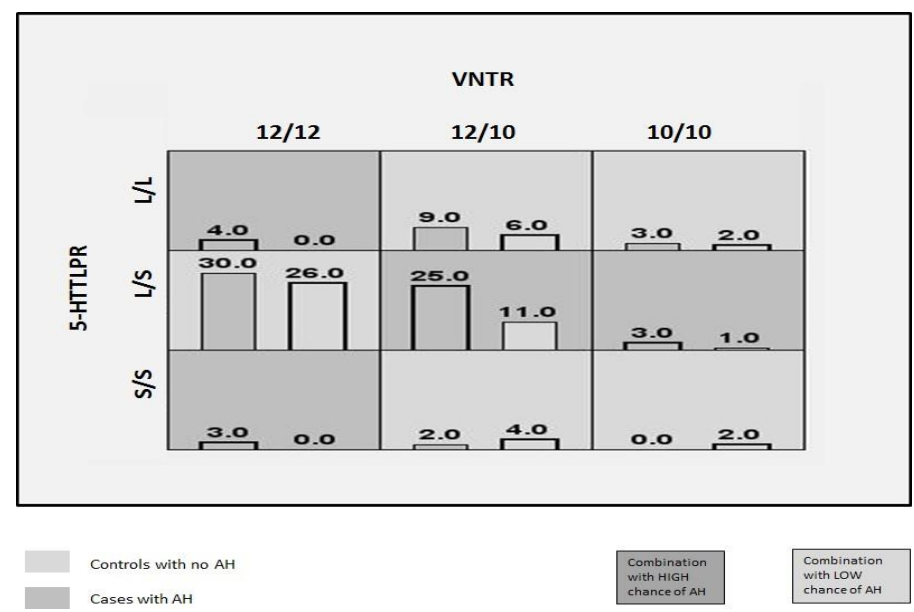

Figure 2: Distribution of the VNTR and 5-HTTLPR genotype combinations in cases and controls in application of MDR.

The two-locus model demonstrating effect of VNTR and 5-HTTLPR which are able to correctly predict $A H$ with $52.2 \%$ accuracy. The 5-HTT $10 / 10+L / S, 12 / 12+L / L, 12 / 12+S / S$ and 10/12+L/S diplotypes had a $3-$ fold, $\infty$-fold, $\infty$-fold and 2.2-fold increased risk of ATH, respectively. For each genotype, the number of cases is displayed in the histogram on the left in each cell while the number of controls is displayed by the histogram on the right. Darker shade indicates those combinations that were classified as high-risk in the original analysis while lighter shade indicates those combinations that were classified as low-risk in the original analysis. Note that the pattern of high and low risk for the 5-HTTLPR differs depending on the value of the VNTR (TBA: 0.522, CVC 10/10, OR 1.2013, CI 0.129-11.1888, P=0.013).

\section{DISCUSSION}

In the current study, we investigated the role of 5-HTTLPR and VNTR polymorphisms of 5-HTT gene, which are localized in the promoter and the intronic region, and their functional properties in ATH. While there were no differences between the children with ATH and control group in terms of genotypes of the two SNPs and variant allele frequency at the VNTR polymorphism. The $\mathrm{S}$ allele of the 5-HTTLPR and the 10/S haplotype of the VNTR_5-HTTLPR occurred more frequently in the control group than in the children with ATH. However, the frequency of these polymorphisms was similar between the subgroups of children with ATH that underwent tonsillectomy, adenoidectomy and both adenoidectomy and tonsillectomy at the same time. Also, we found that the combinations constructed by minor allele of these polymorphisms and were protective effect against ATH.

5-HTTLPR and VNTR are the most extensively and best characterizedofthesenon-codingvariantsof 5-HTT gene.Although there are studies that have investigated the relationship of 5-HTT gene polymorphisms with various diseases, there its relationship with ATH has not been investigated yet. Polymorphism of 5HTT is studied as a pathophysiologic mechanism in many diseases but to the date there is no known report exists that evaluate the role in ATH. In the present study, the frequencies of VNTR allele were similar between the two groups in, and a protective effect of minor allele of 5-HTTLPR against ATH was observed. In this study, the frequency of VNTRL allele were similar in both groups but the minor allele of 5-HTTLPR had protective effect against ATH. In addition, the genotype distribution of VNTR and 5-HTTLPR in genotype analysis was similar across the groups in all genetic models; however, the single-locus model in MDR analysis showed that the S/S genotype of 5-HTTLPR had 1.2-fold higher protective effect against ATH.

According to genotype analysis in all genetic models, distribution of VNTR and 5-HTTLPR was similar but in MDR analysis according to single locus model, 1.2-fold increased protective effect of S/S genotype against ATH was observed. The expression of 5-HTT is regulated by complex transcriptional mechanisms. S allele of 5-HTTLPR and genotypes involving 10 alleles of VNTR were reported to cause a decrease at the level of 5-HTT gene expression in lympblasts (18). In the present study, the haplotype analysis showed that 10/S haplotype had high frequency in the control group and showed a protective effect (2.47-fold). In addition, according to the double-locus model obtained from the MDR analysis, children carrying the harboring 10/10+S/S diplotype was protected (by 1.2-fold) against ATH. It is, however, interesting that $10 / 10+\mathrm{S} / \mathrm{S}$ diplotype was observed only in the control group and 12/12+S/S and 12/12+L/Ldiplotypes were observed only in the patient group. Although our study does not include functional analysis we consider that homozygous combinations of minor alleles of the two polymorphisms might provide a protective effect against ATH phenotype by changing the level of 5-HTT gene expression at lymphoblast in adenoid 
A

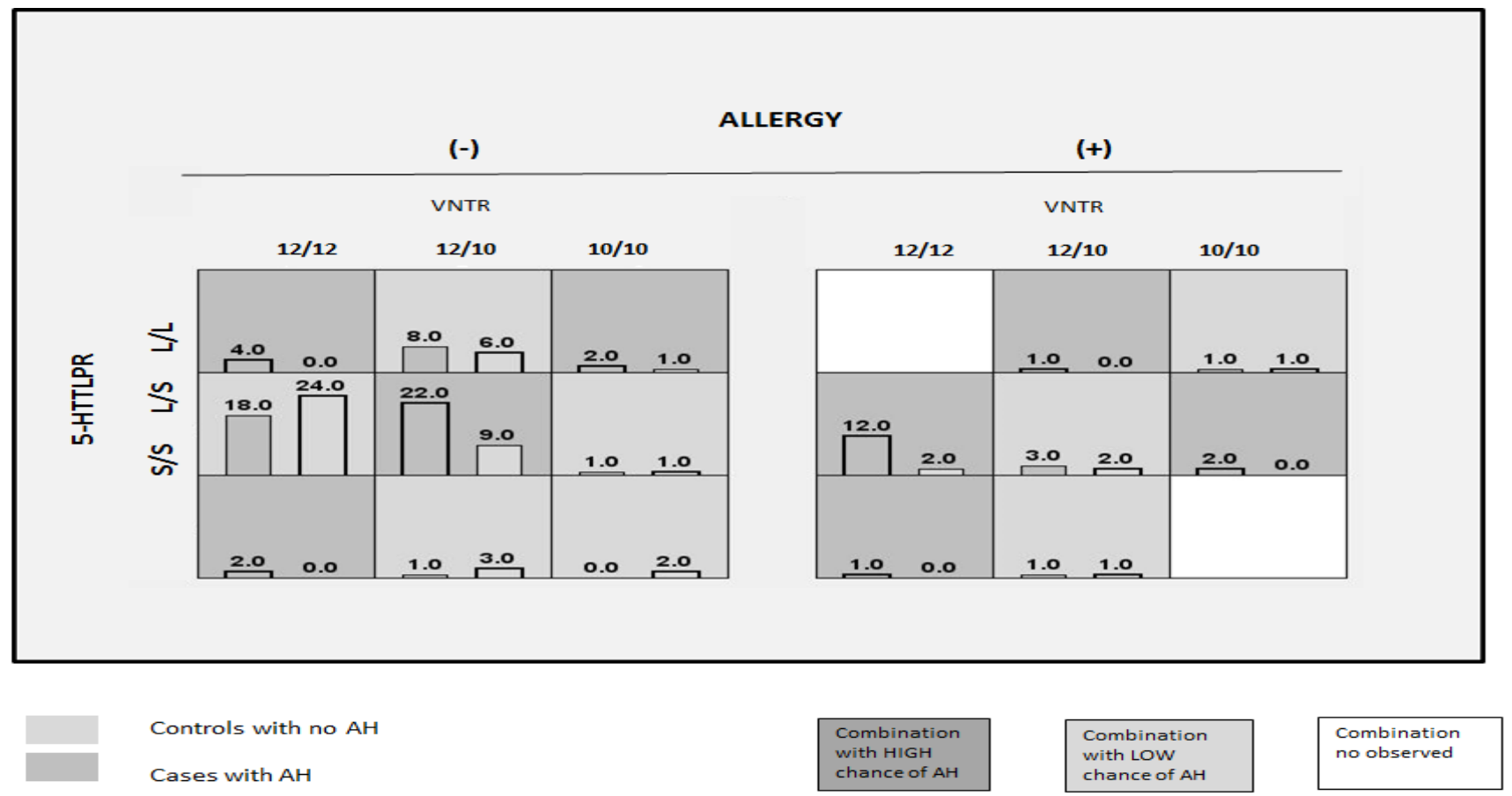

B

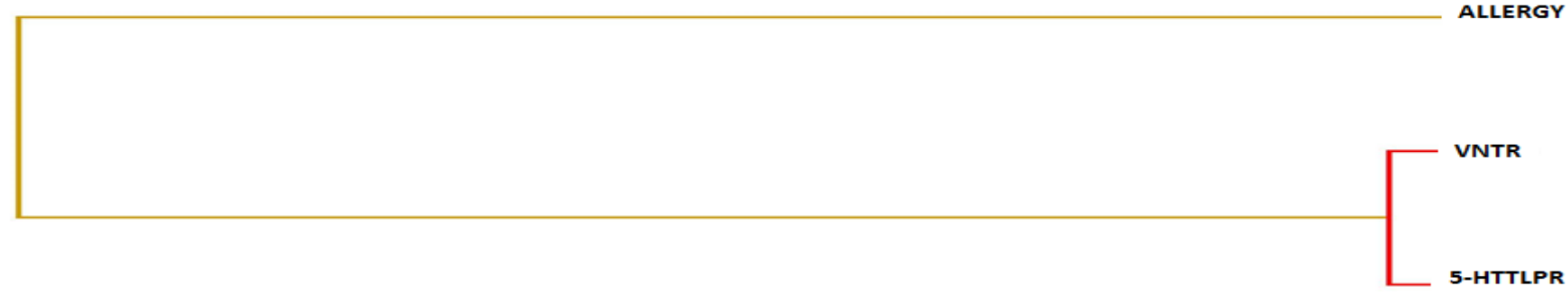

Figure 3: Distribution of the VNTR and 5-HTTLPR genotypes, and allergy combinations in cases and controls in application of MDR.

A. Three-factors model demonstrating effect of the VNTR and 5-HTTLPR genotypes, and allergy combinations which are able to correctly predict AH with $56.3 \%$ accuracy. The 5-HTT 10/10+L/S, 12/12+L/S, 12/12+S/S and 12/10+L/S diplotypes had a $\infty$-fold, 6-fold, $\infty$-fold and $\infty$-fold increased risk of allergic-ATH, respectively. For each genotypes combination, the number of cases with allergy (positive or negative skin prick test) is displayed in in the histogram on the left in each cell while the number of controls with allergy (positive or negative skin prick test) is displayed by the histogram on the right. Darker shade indicates the high-risk group. Note that the pattern of high and low risk for the 5-HTTLPR differs depending on the value of the allergy (negative or positive skin prick test (TBA 0.563, CVC 10/10, OR 4.6465, CI 2.1195-10.1861, P= $<0.0001$ ). B. The dendrogram demonstrates the nature of the interactions between the VNTR, 5-HTTLPR, and allergy included in the genetic classifier obtained by MDR. There was synergistic interaction, with the strongest interaction between the VNTR and 5-HTTLP.

and tonsillar tissues that have mucosal lymphoid tissue character. The serotonin, as an immune regulator molecule, plays a role in inflammatory reactions including allergic inflammation in which basophils, platelets, and mast cells are involved (19). Serotonin has important effects on respiratory function. Also, it has been reported that changes in plasma serotonin levels may play important roles in the pathogenesis of ATH, asthma, and allergy that share a common genetic background (20-23). In the present study, the MDR analysis of 5-HTT gene showed an important synergistic interaction between the two polymorphisms and allergy in three-factor interaction model. In addition, $12 / 12+\mathrm{L} / \mathrm{L}$ and 10/10+S/S diplotypes of 5-HTT were not observed in allergic children in the study group. We suggest that children carrying harboring 10/10+L/S, 12/12+L/S, 12/12+S/S, and 12/10+L/S diplotypes may have increased the risk for allergic-ATH.

In contrast to single-gene disorders, many genetic and environmental factors including gene polymorphisms are combined to produce a cumulative effect that creates the disease phenotype in complex diseases (24). In complex diseases as ATH, in other words, in the absence of a primary effect influencing the disease phenotype MDR analysis acts as a data mining approach to determine and characterize interactions of the parameters, which cannot be determined using other models, and endeavor to explain disease pathogenesis $(15,25,26)$. In the present study, MDR analysis showed the best single (5-HTTLPR), double-locus (5-HTTLPR_VNTR), and three-factor interactions by setting the level of statistical significance as $P=0.001$. These observed interactions were considered as the best MDR models among other models in the study. In the present study, the data obtained with MDR are consistent with the data obtained from genotype, haplotype, and regression analyses. Besides, new and specific data that cannot be determined with these analysis methods were 
obtained with MDR analysis, and it was realized that these data imply more than a simple SNP+SNP or SNP+phenotype $(1+1=$ $3)$. The obtained data with this analysis method supported the hypothesis that the 5-HTT gene is important in determining the risk of ATH (25).

Although the studies investigating the 5-HTT gene reported many polymorphisms of this gene, 5-HTTLPR in promotor and VNTR variations in the secondary intronic region are the most studied polymorphism. Besides, the frequencies of these variations in healthy population were published on international web-based databases (www.hapmap.org and http:www.ncbi.nlm. nih.govsnp).

The most common alleles of the 5-HTTLPR are the S allele (14 repeats) and the $\mathrm{L}$ allele (16 repeats). Also, a number of less common alleles of the polymorphism are the minor XS (17-24 repeats) and XL (11-13 repeats) allele variants and these alleles were not observed in this study (5). In our study, the frequency of S allele of 5-HTTLPR in healthy control group was reported to be $46 \%$ in Caucasians (27), $66 \%$ in Native Americans (28), $86 \%$ in Chinese (29), 70\% in Japanese (30), and $48.1-49 \%$ in Turks $(31,32)$. In the present study, frequency of the $\mathrm{S}$ allele of 5-HTTLPR was $50 \%$ in controls that was different than the reports in populations in other parts of the world but consistent with the data on our population. Among VNTR polymorphisms located in the second intron of the 5-HTT gene, 12 and 10 are the most frequently observed alleles, and alleles 7 and 9 may not be found in certain populations due to their very low frequencies (5). In previous studies, frequency of the allele 10 in healthy controls was reported to be $44.5 \%$ in Germany, $32.1 \%$ in Spain, $34 \%$ in Americans of European origin, 24\% in African decent individuals

$(33,34)$ and $33.4-42 \%$ in Turkey $(31)$. In the present study, Alleles 7 and 9 of the VNTR were not found in the study group, and the frequency of allele 10 was $30 \%$ in healthy controls. The frequency for VNTR minor allele detected in the present study is consistent with the reports from other regions of the world and reports on our population. The deviations in minor allele frequency might have been caused by different parameters such ethnicity, geographic area, and the sample size (35). Although the present study included individuals residing in similar geographic regions in the province of our city and its vicinity, lack of data on ethnic origin of the patients is an important limitation of the study.

There are some potential limitations of the present study. The sample size is small to obtain an accurate and reliable data in such a population-based genetic study (35). Therefore, the sample size is one of our important limitations. The present study also did not evaluate the relationship between these polymorphisms and the expression level of 5-HTT protein. In addition to this, phenotypic classification was not used in the patient group due to strict inclusion criteria for ATH. Besides, the study group is hospitalbased and may not actually represent the normal population. Serotonin transporter gene polymorphisms has relation with OSA and asthma severity and adenoid enlargement may have resulted with a multifactorial interaction of these polymorphisms. Despite these limitations, the present study showed protective effects of S/S genotype, 10/S haplotype, and 10/10+S/S diplotype of the 5-HTT gene against ATH. We consider that nucleotide changes in non-coding promotor and intronic regions of the gene may affect transcriptional capacity of the gene and this may change the extent of inflammatory response by affecting the level of gene expression.

We believe that the present study accumulated a preliminary data in an attempt to develop a gene-based diagnosis and treatment strategies in patients with ATH. Nevertheless, the relationship between 5-HTT gene polymorphisms and ATH must be elucidated in advanced functional studies conducted with larger sample size of patients in population-based studies.

Acknowledgment: The current study was approved by the local ethics committee (ID: 99950669/137). There was no involvement in the design or conduct of the study; collection, management, analysis, or interpretation of the data; or preparation, review, or approval of the manuscript.

Conflict of Interest: The authors disclose any source of funds or financial interest and any commercial associations that might pose or create a conflict of interest with information presented in manuscript.

Funding: ??

Informed Consent: ???

\section{REFERENCES}

1. Wysocka J, Hassmann E, Lipska A, Musiatowicz M. Naive and memory $\mathrm{T}$ cells in hypertrophied adenoids in children according to age. Int $\mathrm{J}$ Pediatr Otorhinolaryngol. 2003;67:237-241. https://doi.org/10.1016/S0165-5876(02)00374-9

2. Messner AH. Evaluation of obstructive sleep apnea by polysomnography prior to pediatric adenotonsillectomy. Arch Otolaryngol Head Neck Surg. 1999;125:353-6. https://doi.org/10.1001/archotol.125.3.353

3. Modrzynski M, Zawisza E. An analysis of the incidence of adenoid hypertrophy in allergic children. Int J Pediatr Otorhinolaryngol. 2007; 1:713-9. https://doi.org/10.1016/j.ijporl.2006.12.018

4. Brodsky L. Adenotonsillar disease in children. Pract Paediatr Otolaryngol. 1999;2:15-39.

5. Anguelova M, Benkelfat C, Turecki G. A systematic review of association studies investigating genes coding for serotonin receptors and the serotonin transporter: I Affective Disorders Molecular Psychiatry. 2003;8:574-91. https://doi.org/10.1038/sj.mp.4001328

6. Shabaldina EV, Shabaldin AV, Riazantsev SV, Simbirtsev SV. The role of cytokine gene polymorphisms in the development of hypertrophy of the tonsils of the lymphoid pharyngeal ring and atopic march in the children. Vestn Otorinolaringol. 2013;6:18-23.

7. Ozdas S, Ozdas T, Acar M, Erbek SS, Koseoglu S, Gokturk 
G, Izbirak A. Association of Interleukin-10 gene promoter polymorphisms with obstructive sleep apnea. Sleep Breath. 2016;20:855-66.

https://doi.org/10.1007/s11325-015-1216-9

8. Xu H, Guan J, Yi H, Yin S. A systematic review and metaanalysis of the association between serotonergic gene polymorphisms and obstructive sleep apnea syndrome. PloS ONE. 2014;9: e86460.

https://doi.org/10.1371/journal.pone.0086460

9. Schroder CM, Primeau MM, Hallmayer JF, Lazzeroni LC, Hubbard JT, O'Hara R. Serotonin transporter polymorphism is associated with increased apnea-hypopnea index in older adults. International Journal of Geriatric Psychiatry. 2014;29:227-35.

https://doi.org/10.1002/gps.3994

10. Lechin F, van der Dijs B, Orozco B, Lechin M, Lechin AE. Increased levels of free serotonin in plasma of symptomatic asthmatic patients. Ann Allergy Asthma Immunol. 1996;77:245-53.

https://doi.org/10.1016/S1081-1206(10)63263-2

11. Veasey SC. Serotonin agonists and antagonists in obstructive sleep apnea: therapeutic potential. Am J Respir Med. 2003;2:21-9.

https://doi.org/10.1007/BF03256636

12. Baugh RF, Archer SM, Mitchell RB, Rosenfeld RM, Amin

R, Burns JJ, Darrow DH, Giordano T, Litman RS, Li KK et al. Clinical practice guideline: tonsillectomy in children. Otolaryngol Head Neck Surg. 2011;144:1e30. https://doi.org/10.1177/0194599810389949

13. Ameli F, BrocchettiF, Semino L, Fibbi A. Adenotonsillectomy in obstructive sleepapnea syndrome, Proposal of a surgical decision taking algorithm. Int J Pediatr Otorhinolaryngol. 2007;71:729-34. https://doi.org/10.1016/j.ijporl.2007.01.007

14. Busse WW. Asthma diagnosis and treatment: filling in the information gaps. J Allergy Clin Immunol. 2011;28:740-50. https://doi.org/10.1016/j.jaci.2011.08.014

15. Sole X, Guino E, Valls J, Iniesta R, Moreno V.SNPStats: a web tool for the analysis of association studies. Bioinformatics. 2006;22:1928-9. https://doi.org/10.1093/bioinformatics/bt1268

16. Aydin S, Sanli A, Celebi O, Tasdemir O, Paksoy M, Eken M, Hardal U, Ayduran E. Prevalence of adenoid hypertrophy and nocturnal enuresis in primary school children in Istanbul, Turkey. Int J Pediatr Otorhinolaryngol. 2008;72:665-8. https://doi.org/10.1016/j.ijporl.2008.01.028

17. Pang H, Jung SH. Sample size considerations of predictionvalidation methods in high-dimensional data for survival outcomes. Genet Epidemiol. 2013;37:276-82.

https://doi.org/10.1002/gepi.21721

18. Hranilović D, Bujas-Petković Z, Tomicić M, BordukaloNiksić T, Blazević S, Cicin-Sain L. Hyperserotonemia in autism: activity of 5HT-associated platelet proteins. J Neurol
Transm (Vienna). 2009;116:493-501. https://doi.org/10.1007/s00702-009-0192-2

19. Kim TH, An SH, Cha JY, Shin EK, Lee JY, Yoon SH, Lee YM, Uh ST, Park SW, Park JS, et al. Association of 5hydroxytryptamine (serotonin) receptor $4(5$-HTR4) gene polymorphisms with asthma. Respirology. 2011;16:630-8. https://doi.org/10.1111/j.1440-1843.2011.01963.x

20. Lau WK, Chan-Yeung MM, Yip BH, Cheung AH, Ip MS, Mak JC. COPD Study Group of the Hong Kong Thoracic Society. The role of circulating serotonin in the development of chronic obstructive pulmonary disease. PLOS ONE. 2012; 7:e31617. https://doi.org/10.1371/journal.pone.0031617

21. Kang BN, Ha SG, Bahaie NS, Hosseinkhani MR, Ge XN, Blumenthal MN, Rao SP, Sriramarao P. Regulation of serotonin-induced trafficking and migration of eosinophils. PLoS ONE. 2013;8:e54840. https://doi.org/10.1371/journal.pone.0054840

22. Barnes KC. Evidence for common genetic elements in allergic disease. J Allergy Clin Immunol. 2000; 06:192-200. https://doi.org/10.1067/mai.2000.110150

23. Olusesi AD, Undie NB, Amodu JE. Allergy history as a predictor of early onset adenoids/adenotonsillarhypertrophy among Nigerian children. Int J Pediatr Otorhinolaryngol. 2013;77:1032-5. https://doi.org/10.1016/j.ijporl.2013.04.004

24. Scott LJ, Mohlke KL, Bonnycastle LL, Willer CJ, Li Y, Duren WL, Erdos MR, Stringham HM, Chines PS, Jackson $\mathrm{AU}$, et al. A genome-wide association study of type 2 diabetes in Finns detects multiple susceptibility variants. Science. 2007;316:1341-5. https://doi.org/10.1126/science.1142382

25. Moore JH. A global view of epistasis. Nat Genet. 2005;37:134. https://doi.org/10.1038/ng0105-13

26. Babademez MA, Ozdas T, Ozdas S. The common genetic variants of toll-like receptor and susceptibility to adenoid hypertrophy: a hospital-based cohort study. Turk J Med Sci. 2016;13:46-56. https://doi.org/10.3906/sag-1511-16

27. Jacobs N, Kenis G, Peeters F, Derom C, Vlietinck R, van Os J. Stress-related negative affectivity and genetically altered serotonin transporter function: evidence of synergism in shaping risk of depression. Arch Gen Psychiatry. 2006;63:989-96. https://doi.org/10.1001/archpsyc.63.9.989

28. Hu XZ, Lipsky RH, Zhu G, Taubman J, Greenberg BD, Xu K, Arnold PD, Richter MA, Kennedy JL, Murphy DL et al. Serotonin transporter promoter gain-of-function genotypes are linked to obsessive-compulsive disorder. Am J Hum Genet. 2008;78:815-26. https://doi.org/10.1086/503850

29. Shen Y, Li H, Gu N, Tan Z, Tang J, Fan J, Li X, Sun W, He 
L et al. Relationship between suicidal behavior of psychotic inpatients and serotonin transporter gene in Han Chinese. Neurosci Lett. 2004;372:94-8. https://doi.org/10.1016/j.neulet.2004.09.018

30. Narita N, Narita M, Takashima S, Nakayama M, Nagai T, Okado N. Serotonin transporter gene variation is a risk factor for sudden infant death syndrome in the Japanese population. Pediatrics. 2001;107:690-2. https://doi.org/10.1542/peds.107.4.690

31. Yilmaz M, Erdal ME, Herken H, Cataloluk O, Barlas O, Bayazit YA. Significance of serotonin transporter gene polymorphism in migraine. J Neurol Sci. 2001;186:27-30. https://doi.org/10.1016/S0022-510X(01)00491-9

32. Akar T, Sayin A, Bakkaloglu Z, Cabuk DK, Kucukyildirim S, Demirel B, Candansayar S, Ozsoy ED, Mergen H. Investigation of serotonin transporter gene promoter (5HTTLPR) and intron 2 (variable number of tandem repeats) polymorphisms with suicidal behavior in a Turkish population. DNA Cell Biol. 2010;29:429-34.

https://doi.org/10.1089/dna.2010.1031

33. Klauck SM, Pautska F, Benzer A. Serotonin transporter (5HTT) gene variants associated with autism. Hum Mol Genet. 1997;6:2233-5.

https://doi.org/10.1093/hmg/6.13.2233

34. Gelertner J, Kranzler H, Coccaro E. Serotonin transporter protein gene polimorphism and personlality measures in African American and Europen American Subjects. Am J Psychiatry. 1998;155:1332-8. https://doi.org/10.1176/ajp.155.10.1332

35. Fareed M, Afzal M. Single nucleotide polymorphism in genome-wide association of human population: A tool for broad spectrum service. Egypt J Med Hum Genet. 2013;14:123-3

https://doi.org/10.1016/j.ejmhg.2012.08.001 